\title{
Office Work Innovation: What about Wellbeing?
}

\author{
Veerle Hermans ${ }^{1,2,3}$ \\ ${ }^{1}$ Faculty of Medicine and Pharmacy (Mental Health and Wellbeing Research Group), Vrije Universiteit Brussel, \\ Brussel, Belgium \\ ${ }^{2}$ Faculty of Psychology and Educational Sciences (Work and Organisational Psychology Research Group), Vrije \\ Universiteit Brussel, Brussel, Belgium \\ ${ }^{3}$ IDEWE (External Service for Safety and Health at Work), Heverlee, Belgium \\ Email: veerle.hermans@idewe.be
}

Received 24 May 2016; accepted 18 July 2016; published 21 July 2016

Copyright @ 2016 by author and Scientific Research Publishing Inc.

This work is licensed under the Creative Commons Attribution International License (CC BY).

http://creativecommons.org/licenses/by/4.0/

(c) () Open Access

\begin{abstract}
Offices nowadays are looking very attractive: design furniture, trendy colours, fancy lighting, art objects and even an ecological touch. These offices are often linked to new ways of working, further explained by concepts such as flex work, telework, shared office work, cloud work etc. But what are the effects of these changing environments on the wellbeing of the workers? And do these trendy offices really increase ergonomics at work? In this paper, first a brief history on the development and evolution of office environments is given. Furthermore, an analysis of some pitfalls in today's offices is presented. For each pitfall, some advice is given on how to reduce the problems.
\end{abstract}

\section{Keywords}

Offices, Innovation, Wellbeing, Ergonomics

\section{A Brief History of Office Innovations}

Already from the start of offices, innovation has been a key issue. It was and is a continuous evolution in the search for company efficiency and wellbeing of workers.

\subsection{Antiquity}

We are far from the scribes in Ancient Egypt who read papyri (paper-like material from het papyrus plant) in a seated position on the floor with the text on their lap. They were considered part of the royal court and were exempt from the heavy manual labor required of the lower classes [1]. Also monks in the Middle Ages had a 
certain status and importance by their literacy in reading and writing Latin. They copied manuscripts to help preserve ancient literature for future generations. Rarely a "Scriptiorium" was found in a monastery, a specific room for writing, next to the library. Most monastic writing was done in cubicle-like recesses, or writing-desks [2]. The father of occupational medicine, Bernardino Ramazinni, was the first who described the risks associated with this type of work [3]:

"First, constant sitting, secondly the incessant movement of the hand and always in the same direction, thirdly the strain on the mind from the effort not to disfigure the books by errors or cause loss to their employers when they add, subtract, or do other sums in arithmetic...”

Although this was already originally written in 1713, today we still notice the same problems in offices: sustained sedentary work (e.g. Biswas e.a. 2015), musculoskeletal disorders during typing (e.g. Rempel e.a. 2008 [4]) and sustained cognitive efforts (e.g. Hollender e.a. 2010 [5]).

\subsection{Industrial Revolution}

New machines such as the telegraph, telephone and typewriters increased and fastened information processing. Inspiration for office design came from the Taylor principles: repetitive work, in rows next to each other and in big spaces, so-called open plans. An example is given in Figure 1. This caused a good visual supervision from management, who of course supervised from their own separate office room. All machinery was put close by, which thus was a direct cause of the development of sustained sedentary work [6].

\subsection{From the 50's to the 70's}

In Germany, they decide to divide the open plan model with screens, walls and plants to create differentiation and privacy (for an example, see Figure 2). Carpet and absorbing ceilings had to reduce the noise level. Advantages

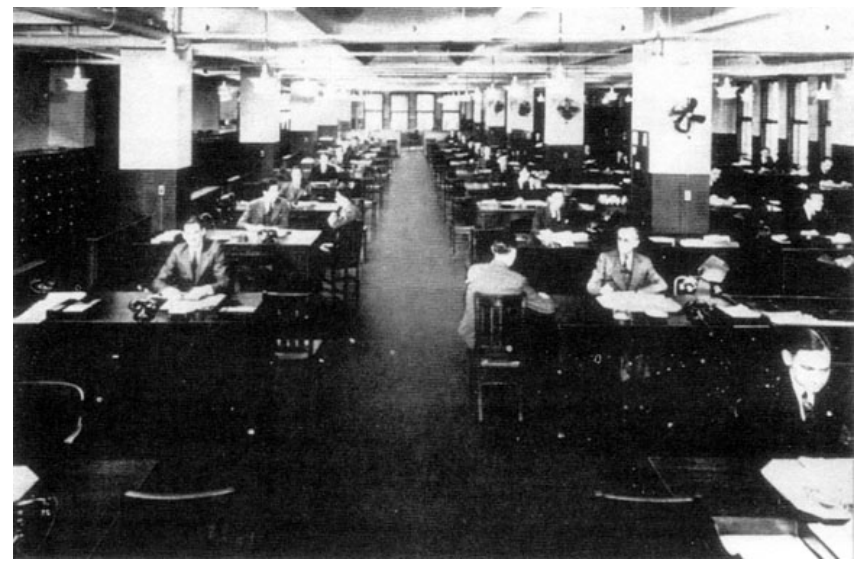

Figure 1. Set-up of office workstations during the industrial revolution http://www.carusostjohn.com/.

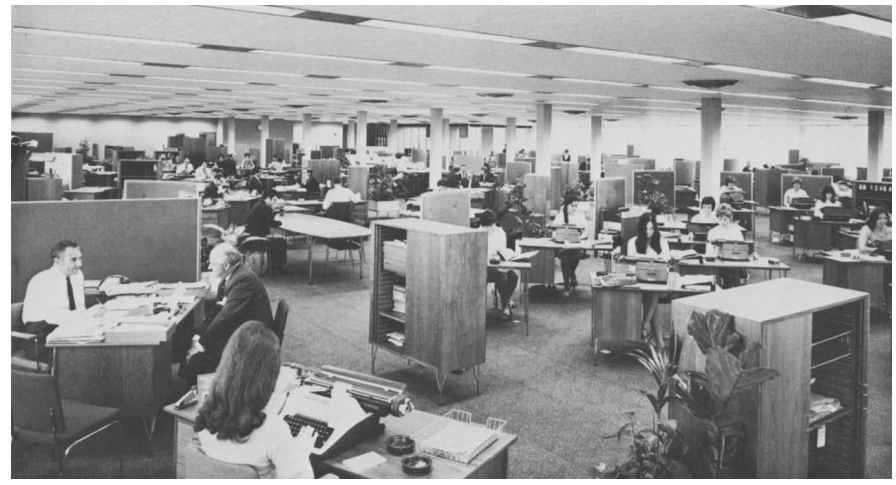

Figure 2. First version of an open office plan (Brookes, 1972) [7]. 
of these types of offices were given: reduction in space, less maintenance costs, increase in productivity and even less absenteeism (Brookes, 1972) [7].

\subsection{The 80's and 90's}

Driven by technological innovations and the fast developing changes in computers, changes in the workplace station took place. A specific sub-discipline in ergonomics that analysed the impact of all these changes was born: office ergonomics. Emphasis was put on a good basic posture during work at a computer screen, so that musculoskeletal load of the upper limbs was minimised. This is important, since several reviews indicate a possible causal relationship between computer work and musculoskeletal complaints in the neck and arm [8]. An ISO standard was developed from this, taking into account the set-up of the workstation, but also requirements of hardware and software: "Ergonomic requirements for office work with visual display terminals (VDTs)"ISO 9241 (developed from 1993 on). Also legislation emerged from this, e.g. in Europe the Council Directive 90/270/EEC of 29 May 1990 on the minimum safety and health requirements for work with display screen equipment was presented. This caused an increasing amount of attention in offices regarding a good basic computer workplace set-up and the development of checklists to analyse the set-up. Also emphasis went to a good knowledge of workers regarding prevention of musculoskeletal disorders when working at a computer workplace.

Also the first signs of teleworking came on the agenda, due to the increase in information technology [9]. Flexible work is introduced which means a work practice allows employees a certain amount of flexibility in respect of time, place and duration of work [10]; also referred to as New Ways of Work (NewWoW) [9].

\subsection{0+: New Ways of Work}

With the revolutionary increase in mobile technologies and communication media, the number of employers making extensive use of NewWoW has increased tremendously. A better organisation of knowledge work takes place, and working from other places than from the office is possible. Two important strategic objectives were formulated with respect to office accommodation: an economic objective (higher profitability) and a social objective (increased well-being of workers) [11]. The optimal balance between organisation and accommodation may promote efficient work, higher job satisfaction, more productivity and a reduction in facility costs. This was reflected in the office accommodation firstly by the creation of shared open-plan offices: no individual owners of a workstation, but first come, first served principle: the sooner you arrive at the office, the larger the choice where to sit for the rest of the day in the landscape environment. This was only possible due to the provision of individual adjustable furniture (chair and table). Secondly, and often considered most important, less workstations than the total number of workers are necessary: more workers work from home, satellite or other locations; also more part-time workers are found, so less office space and workstations are necessary. Regarding accommodation at the office, NewWoW seem to be an enabler to rethink office design to create an inspirational and productive physical working environment. At the same time contemporary management theories are implemented to create a mental work environment, targeting both the organisation and its workers [12].

\section{Analysis of Today's Wellbeing Pitfalls}

Besides the good news show of economic and social advantages of today's workstations, studies have unfortunately proven that the benefit in space reduction often caused other investments. There is a need for more information and communication technology, renovation costs, more expenses in furniture (not only at the office, but also at home and/or at satellite offices), costs for external and internal project developers, etc. [13]. But also regarding the social wellbeing objective, the transition from traditional towards innovative offices didn't always result in positive effects [14]. It is strikingly that the problems already mentioned by Ramazinni (sedentary work, mental overload and physical problems), still appear today... Let's have a look at some of the pitfalls in today's offices and how to reduce them.

\subsection{Bye, Bye to Classic Physical Ergonomics}

The number of office workers still increases tremendously. If we want to avoid that even more physical complaints are found in offices, than we have to hold on onto the basic ergonomic rules of the set-up of a computer workstation, as explained in the ISO standard 9241. In research, there is evidence that demonstrates the effec- 
tiveness of interventions, in reducing both the exposure to potential workplace risk factors and the prevalence of work-related musculoskeletal disorders. One study revealed that there was even a US \$17.8 return on investment for every dollar invested in an ergonomics intervention strategy. Also further cost savings in worker compensation were mentioned [15].

So advice should be given to workers how to set-up a computer workstation correctly (see Figure 3 as an example of a traditional work station set-up). A computer workstation checklist can be used to analyse the necessary requirements (for example: https://www.osha.gov/SLTC/etools/computerworkstations/checklist.html).

Since 1995, the number of laptops in companies increased tremendously. Research to awkward postures when working with these devices, followed soon [16]. After the laptops, smartphones came. Hansraj [17] demonstrated that when performing concentrated tasks on a smartphone, our head bents on average $60^{\circ}$, which is translated in 27 extra kg for the cervical spine. The same posture problems can be found when working with tablets (Young et al., 2012). Fortunately, helping devices such as a laptop holder and attached keyboard and mouse optimise the working postures. Also for tablets, helping devices can be found to put the tablet at a higher position, although an ideal situation will not be created [11].

Unfortunately, in recent trendy working environments, we often find situations in which these basic requirements are forgotten. For example: A trendy chair that rather fits at a reception, a coffee corner, or a short brainstorming meeting place, than at the office desk since no individual adjustability is possible; or large bench desks for 3 workers and more, with no individual height adjustability; or the provision of a sit-stand table to reduce sitting time (see also pitfall 3), but no accessories to put the laptop at a correct height.

Also regarding home workstations, workstations often seem to be insufficient. In a study across 4 European countries most HR professionals claim that an ergonomic workstation is essential for flexible working, however regarding the home workstation having the same requirements as the office station, percentages are much lower [10]. A home workstation for which the employer actually offers tools and accessories varied between $42 \%$ and

\section{Are you sitting comfortably?}

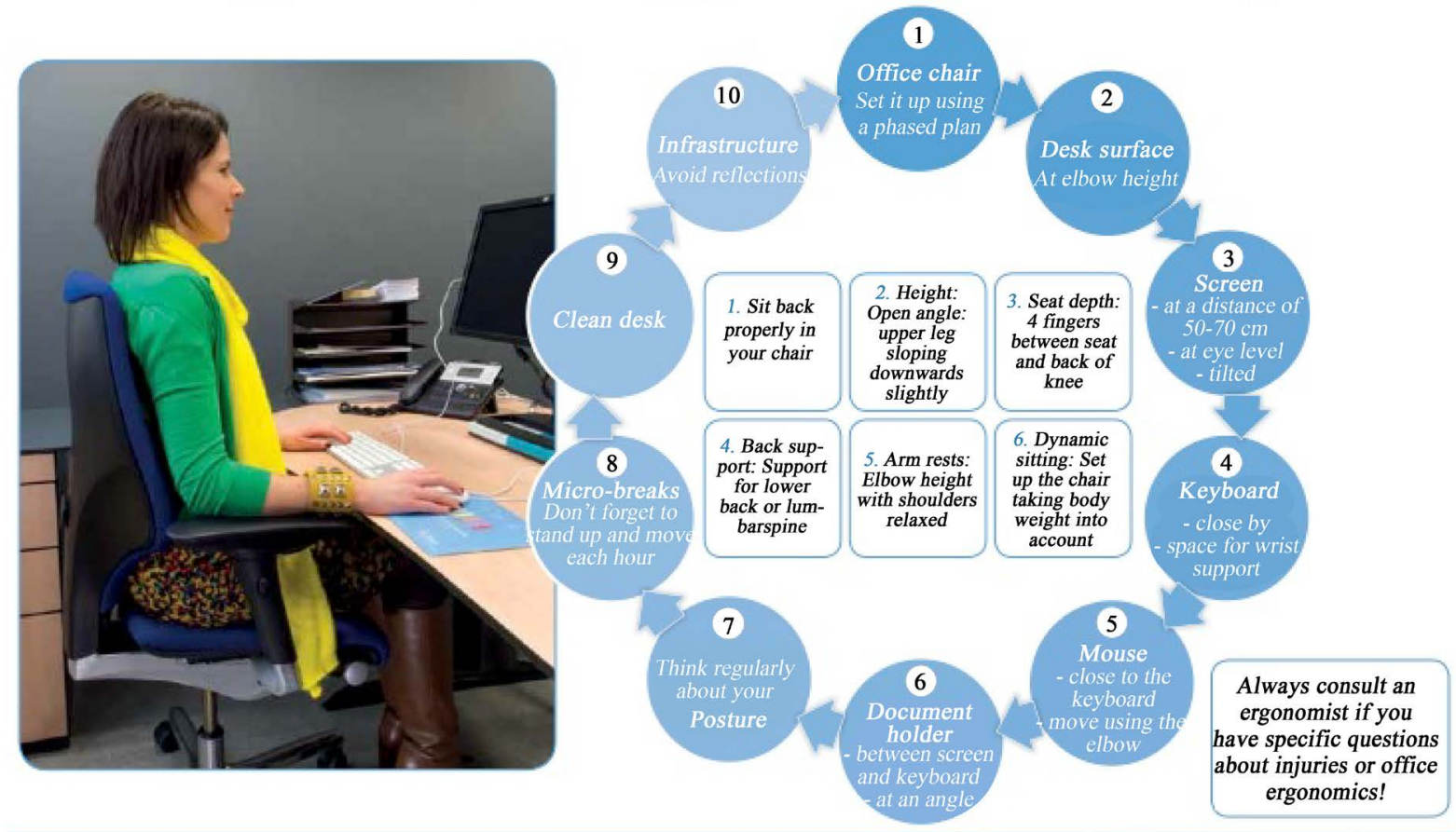


$63 \%$ across countries.

Advice: Integrate the basic ergonomic rules regarding workstation set-up at all types of flexible work stations (in the office but also at home). A clear message should be given that sustained use of laptops should be avoided without the use of helping devices. Regarding tablets, also helping devices could be used but even when using these devices, working time should be limited

\subsection{Paradox of the Two C's: Concentration and Communication}

Already in the 70's, research revealed that both aspects of concentration and communication are in continuous conflict in an open space office [7]. A high satisfaction can be found regarding the communication between workers in a shared office environment, and this for formal and informal meetings, and for small chats between colleagues [18]. However, when concentration tasks have to be performed, the communication disturbs the work of other office workers [19]. Furthermore, workers sharing an open-plan office, have significantly more days of sickness absence than occupants in cellular offices, in 2-persons offices or in 3 - 6 person offices [20].

Besides colleagues, there are other concentration-disturbing sources, the so-called digital confounders. Obviously, new technologies can be seen as adding to the modern worker's arsenal: information is available anytime and anywhere, communication is easier with clients and colleagues and the technology is becoming faster and faster. Jobs go into the cloud today, work becomes fractionalized and workers are less at the office. People are virtual nowadays and have the freedom to be an entrepreneur, the so-called virtual preneur [21]. But this mobile work can be a double edged sword. The downside is that it can increase cognitive and psychosocial work stress when the possibilities that the new technology offers, becomes pressure [9]. The so-called techno-stress may even lead to techno-addiction. Furthermore, the drive to be continuously online and to be reachable by phone, computer, tablet, even within seconds, causes a lot of multitasking, which has proven to decrease efficient work [22]. Apart from lower productivity, also health problems may arise: overworking, overtiredness, chronic fatigue, burn-out etc. Also possible neurological effects may arise known as "attention deficit trait": workers find it difficult to keep organised, set priorities and manage their time [9]. And if this is not enough, also excessive pragmatism, soloist behaviour, and a loss of social cohesion and a disturbed work/life balance appear [9]. Therefore, some companies decided to ban home work again, since they are equating workplace productivity with real time at the office. The company memo, from human resources chief Jackie Reses at Yahoo, read: "Some of the best decisions and insights come from hallway and cafeteria discussions, meeting new people, and impromptu team meetings."

(http://www.businessinsider.com/yahoo-working-from-home-memo-2013-2?IR=T). Other companies try to solve the collaboration and innovation problems by using e.g. digital tools

(http://www.zdnet.com/article/todays-enterprise-collaboration-landscape-cloudy-social-mobile/). Once again, the integration of these digital tools should be done wisely, taking into account both aspects of communication and concentration.

Advice: Besides the landscape workplaces at the office, sufficient concentration workplaces or zones of "do not disturb" should be available for knowledge workers. Instead of creating a large open-plan office, working zones of max. 6 persons are promoted.

Protect yourself from digital attraction. Create periods of "no disturbing" in your own work practices: e.g. read emails or messages only during fixed time zones during the day or organise virtual meetings at specific time slots. Other important recommendations are: detach from work, develop a strong work-home boundary and relax. Regarding organisations, the following recommendations are mentioned: enhance employee control, provide support to employees and reduce expectations for long hours (Carolyn Axtell, mentioned in Bruck and Rao 2013 [23]).

\subsection{And Last but Not Least... Today's Sitting Problem}

With the increasing amount of office workers, more and more people increase their sitting behaviour. It is proven that increased sitting time at work, increases the risk of cardiovascular disease, obesity, diabetes and even earlier mortality (e.g. Chau et al., 2013, Biswas et al., 2015). The reason for this is that the work normally performed by the large skeletal muscles in the legs, back, and trunk during standing and moving, comes to a halt when sitting. This has an effect on the cellular regulation of skeletal muscle lipoprotein lipase (a protein important for controlling metabolic risk factors such as cholesterol) (Hamilton et al., 2007). Therefore, employees should be encouraged to change and break up their sitting behavior. The best way to do this is to replace sitting with light to moderate intensity physical activity. There are several possibilities to do this: changes in the work- 


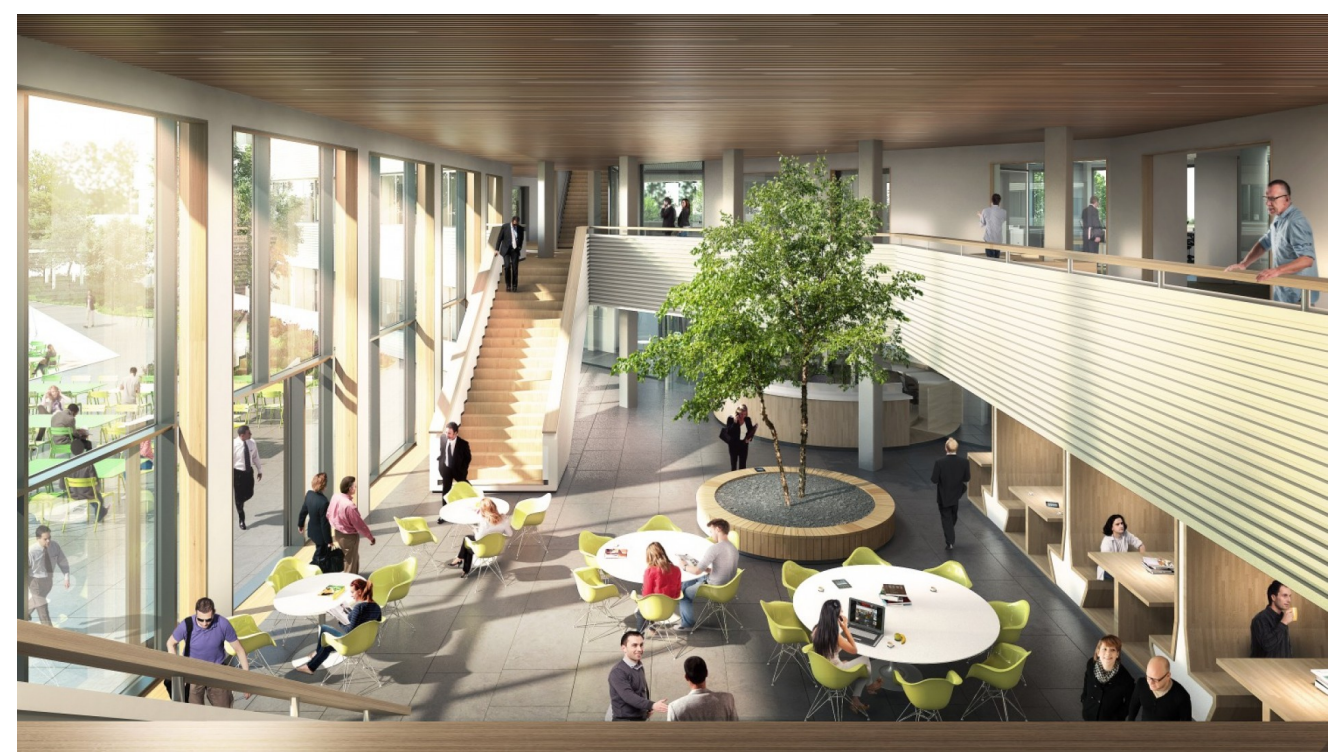

Figure 4. Example of a dynamic working environment (http://www.kraaijvanger.nl/image/1/0/1080/0/uploads/project-afbeeldingen/3121_84_n9_medium-545b763ad6bae.jpg).

place environment and design (e.g. separate printer room, promotion of stair use, provision of a ping-pong table) or changes in the design of office desks (e.g. use of sit-stand tables, ergobikes, treadmill desks). A lot of new devices are coming into the market. The effectiveness of these interventions is a popular theme in recent research. A recent review study [24] revealed that sit-stand desks can reduce sitting between a half to two hours per day. Also people will reduce their sitting periods lasting longer than $30 \mathrm{~min}$. However, one study analysed the effects after 6 months and found that sitting was reduced with less than one hour. This is considerably less than the 2 till 4 hours that is promoted by an expert guideline (Buckley et al., 2015). So it is extremely important to focus on strategies to promote behaviour change to reduce our sitting behaviour. Also, standing alone is not enough to have sufficient change in your energy expenditure during the day, therefore it is recommended not only to break sitting with standing periods, but also to move more during work.

Advice: follow recent research regarding the effectiveness of new devices and interventions. Integrate different principles into a dynamic office: promote changes in the general workplace environment, in the workstation lay-out and in the organisation of work. For an example of a dynamic working environment, see Figure 4.

\section{Conclusion}

Office workplaces changed considerably over time. The introduction of computers at the workplace led to a classic computer workstation set-up. The increasing number of computer workers and the new ways of working (NewWoW) that emerged in the last decade, caused changes in the office lay-out and organisation of work. Unfortunately, the problems that were already mentioned by Ramazinni in 1713 regarding office workers are still found with the NewWoW workers: sustained seated work, mental overload and physical problems. In this document, suggestions are given to reduce these problems. It is advised to integrate these aspects to the traditional computer workstation analysis and to further develop good practices, requirements and more research regarding today's work at the office. This paper doesn't claim to be comprehensive regarding all wellbeing factors at work. There are other problems or pitfalls that should receive further attention (e.g. ventilation issues in landscape offices, electromagnetic fields with the increasing use of mobile technology or wireless internet, etc.). And also don't forget that besides wellbeing, other themes are important, such as mobile security management.

\section{References}

[1] Rice, M. (2001) Who's Who in Ancient Egypt. Routledge, UK.

[2] De Hamel, C. (1992) Scribes and Illuminators. University of Toronto Press, Toronto.

[3] Ramazzini, B. (2001) De Morbis Artificum Diatriba (Diseases of Workers). American Journal of Public Health, 91, 
1380-1382. http://dx.doi.org/10.2105/AJPH.91.9.1380

[4] Rempel, D.M., Keir, P.J. and Back, J.M. (2008) Effect of Wrist Posture on Carpal Tunnel Pressure While Typing. Journal of Orthopaedic Research, 26, 1269-1273. http://dx.doi.org/10.1002/jor.20599

[5] Hollender, N., Hofmann, C., Deneke, M. and Schmitz, B. (2010). Review: Integrating Cognitive Load Theory and Concepts of Human-Computer Interaction. Journal Computers in Human Behavior, 26, 1278-1288. http://dx.doi.org/10.1016/j.chb.2010.05.031

[6] Lueder, R. (1986) The Ergonomics Payoff: Designing the Electronic Office. Holt, Rinehart and Winston of Canada, Toronto, $16 \mathrm{p}$.

[7] Brookes, M.J. (1972) Office Landscape: Does It Work? Applied Ergonomics, 3, 224-236. http://dx.doi.org/10.1016/0003-6870(72)90105-6

[8] Wahlström, J. (2005) Ergonomics, Musculoskeletal Disorders and Computer Work (In-Depth Review). Occupational Medicine, 55, 168-176. http://dx.doi.org/10.1093/occmed/kqi083

[9] Popma, J. (2013) The Janus face of the 'New Ways of Work': Rise, Risks and Regulation of Nomadic Work. ETUI, Brussels, $44 \mathrm{p}$.

[10] Bakker-Elkhuizen (2013) International Flexible Working Survey. https://www.bakkerelkhuizen.com/international-flexible-working-survey/

[11] Hermans, V. and Pullen, W.R. (2006) Werkbeleving in innovatieve kantooromgevingen. Psychologos, 21, 20-25.

[12] Bijl, D. (2009) Aan de slag met het nieuwe werken. Par CC, Zeewolde, 190 p.

[13] Van der Voordt, D.J.M. and Negen, M. (2001) Meer- en minderkosten van werkplekinnovatie. Facility Management Magazine, 20-26.

[14] Van der Voordt, D.J.M. (2003) Kosten en baten van werkplekinnovatie: Een definitie- en programmeringsstudie. Center for People and Buildings, Delft \& Centrum Facility Management, Naarden. Persbericht \& Boekbespreking \& Webbericht CfPB.

[15] Buckle, P.W. and Devereux, J. (2002) The Nature of Work-Related Neck and Upper Limb Musculoskeletal Disorders. Applied Ergonomics, 33, 207-217. http://dx.doi.org/10.1016/S0003-6870(02)00014-5

[16] Straker, L., Jones, K.J. and Miller, J. (1997) A Comparison of the Postures Assumed When Using Laptop Computers and Desktop Computers. Applied Ergonomics, 28, 263-268. http://dx.doi.org/10.1016/S0003-6870(96)00073-7

[17] Hansraj, K.K. (2014) Assessment of Stresses in the Cervical Spine caused by Posture and Position of the Head. Surgical Technology International, 25, 277-279.

[18] Hermans, V., De Vriendt, L. and de Kyser, A. (2016) Improving Neck Postures during Tablet Use. PREMUS 2016.

[19] Pullen, W. and Bradley, S. (2004) Modernising Government Workplaces: Towards Evidence, as Well as Experience. Facilities, 22, 70-73. http://dx.doi.org/10.1108/02632770410527798

[20] Pejtersen, J.H., Feveile, H., Christensen, K.B. and Burr, H. (2011) Sickness Absence Associated with Shared and Open-Plan Offices-A National Cross Sectional Questionnaire Survey. Scandinavian Journal of Work, Environment \& Health, 37, 376-382. http://dx.doi.org/10.5271/sjweh.3167

[21] Houlne, T. and Maxwell, T. (2013) The New World of Work: From the Cube to the Cloud. Inspire on Puropose Books, Irving, $144 \mathrm{p}$.

[22] Compernolle, T. (2014) Brain-Hostile Open Offices. https://sites.google.com/site/liberateyourbrain/

[23] Bruck, P.A. and Rao, M. (2013) Global Mobile: Applications and Innovations for the Worlswide Mobile Ecosystem. Information Today Inc., New Jersey, 275-292.

[24] Shrestha, N., Kukkonen-Harjula, K.T., Verbeek, J.H., Ijaz, S., Hermans, V. and Bhaumik, S. (2016) Workplace Interventions for Reducing Sitting at Work. Cochrane Database of Systematic Reviews, Article Number: CD010912. http://dx.doi.org/10.1002/14651858.CD010912.pub3 


\section{Submit or recommend next manuscript to SCIRP and we will provide best service for you:}

Accepting pre-submission inquiries through Email, Facebook, LinkedIn, Twitter, etc.

A wide selection of journals (inclusive of 9 subjects, more than 200 journals)

Providing 24-hour high-quality service

User-friendly online submission system

Fair and swift peer-review system

Efficient typesetting and proofreading procedure

Display of the result of downloads and visits, as well as the number of cited articles

Maximum dissemination of your research work

Submit your manuscript at: http://papersubmission.scirp.org/ 